\title{
Turizmde Kadın Akademisyenler
}

Woman Academicians in Tourism

\section{Hatice GÜÇLÜ NERGiZ*}

** Doç. Dr., Kocaeli Üniversitesi, Turizm İşletmeciliği ve Otelcilik Yüksekokulu Konaklama İşletmeciliği Bölümü, 41001, Kocaeli.

E-posta: hg.nergiz@kocaeli.edu.tr

ORCID: 0000-0002-8848-7014

MAKALE BILGILERI

Makale işlem bilgileri:

Gönderilme tarihi: 21 Nisan 2019

Düzeltme: 1 Eylül 2019

Kabul: 20 Eylül 2019

Anahtar sözcükler: Turizm eğitimi,

Toplumsal cinsiyet, Kadin

akademisyen.

\section{ARTICLE INFO}

Article history:

Submitted: 21 April 2019

Resubmitted: 1 September 2019

Accepted: 20 September 2019

Key words: Tourism education, Gender, Woman academicians

\section{ÖZ}

Bu çalışmanın temel amacı, Türkiye'de turizm bilim dalındaki kadın akademisyenlerin mevcut durumunun saptanmasıdır. Bu amaçla, yükseköğretim kurumlarında görevli olan öğretim elemanları ile ilgili veriler derlenerek, farklı değişkenler açısından incelenmiştir. Mart 2019 tarihi itibariyle turizm bilim alanında akademik. yok.gov.tr internet adresinde kayıtlı toplam 1210 öğretim elemanı bulunmaktadır. Bu akademisyenlerden 486'sı kadın akademisyenlerden oluşmaktadır. Araştırmada, farklı akademik pozisyonlardaki turizm bilim dalındaki kadın akademisyenler unvan, görev yaptıkları üniversitenin niteliği (devlet veya vakıf), anahtar kelime gibi değişkenler açısından değerlendirilmiștir. Ayrıca kadın akademisyenler akademik çalıșmaları açısından kitap, makale, bildiri, proje ile öğretim üyeleri yönettikleri tezler açısından incelenmiştir. Araştırmanın sonuçlarına göre, turizm alanında kadın akademisyenlerin unvanlarının yayın türlerine göre anlamlı farklılık gösterdiği tespit edilmiştir.

\begin{abstract}
The main purpose of this paper is to determine the current status of women academics in tourism studies. Therefore, the data associated with the academic members in higher education institutions was compiled and analyzed. The study evaluates woman academicians working in different academic positions in terms of title, the nature of the university and keywords. As of March 2019, there has been a total of 1210 academic members who are registered in tourism. Of these, 486 are women. The study also assesses academics in terms of their academic studies such as their published books, articles, papers, projects, and the thesis supervised. Results determine that the titles of woman academicians in tourism differ significantly according to the types of publications.
\end{abstract}

\section{Giriş}

Yükseköğretim kurumlarının toplumun değer ve normları, gelenek ve görenekleri ile adetlerine göre şekillendikleri (Adak 2018), kurumun yapılanması içinde cinsiyet temelli bir farklılaşmanın olup olmadığı, üzerinde önemle durulması gereken bir konudur (Başarır ve Sarı 2015). Cinsiyet,

\footnotetext{
* Bu çalışma, Dokuz Eylül Üniversitesi Foça Turizm Fakültesi ile Anatolia Turizm Akademisi tarafından 11-14 Ekim 2018 tarihlerinde Foça'da düzenlenen "Hasan Olah Turizm Sempozyumu"nda sunulmuş halinin, yazarlarca daha sonra geliştirilerek, yeniden düzenlenmiş halidir.
}

bireye yönelik toplumsal anlamaları, değerleri, rolleri biçimlendiren, özellikleri ve beklentileri içeren önemli bir sosyal kategori olarak ifade edilmektedir (Ersoy 2009). Dökmen (2004) cinsiyet farklılığının biyolojik farklılıklara dayandığını işaret ederek, kavramın doğuştan gelen yapısal ve fiziksel özelliklerle açılanabileceğini ifade etmektedir. Acker'ın (1992) belirttiği gibi 'cinsiyet', fizyolojik ve biyolojik doğal bir oluşum iken 'toplumsal cinsiyet' bireyin ilerleyen yaşam süreçlerinde aile, meslek, toplum ve kültür etmeni ile şekillenen karmaşık bir oluşumdur. Ada- 
çay (2014) toplumsal cinsiyeti, bireyin biyolojik doğasından kaynaklanmayan, ancak toplumda doğallaştırılmış cinsiyet kimliği olarak ifade etmiştir.

Toplumsal cinsiyet kimliği, toplumdan topluma farklılık gösteren bir kimlik olarak kabul edilmektedir (Mayatürk Akyol 2015: 9). Bu anlamda ele alındığında kadın ve erkek çalışanların kariyer yaşamlarında sahip oldukları unsurlar birbirinden farklı olmaktadır. Öktem ve arkadaşları (2018) çalışan kadınların iş bulma, kariyerinde ilerleme, mesleki eğitim alma, sosyal hak ve ücretlerden yararlanma, yıldırma, cinsel taciz, cam tavan sendromu gibi sorunlarla sıkça karşılaştıklarını ifade etmişlerdir. Türkiye'de hizmet sektöründe istihdam edilen kadınların ağırlıkla eğitim

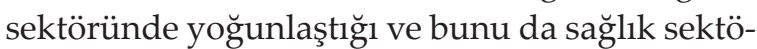
rünün takip ettiği gözlenmektedir (Elmas Arslan 2014).

Cinsiyet ve toplumsal cinsiyet arasındaki ayrışmadan dolayı, kadın ve erkek bireyler arasında cinsiyet temelli bir farklılık söz konusudur. Kadın ve erkek arasında toplumsal cinsiyet aç1sından ise toplumsal yaşama katılım, fırsatların kullanılması, hizmetlere erişim ve kaynakların kullanımı gibi konularda toplum tarafından yapay bir şekilde oluşturulan bir eşitsizlik durumundan söz etmek mümkündür (Başarır ve Sarı 2015).

Kadının toplum içindeki yeri ilk kez Türkiye'de pek çok alanda olduğu gibi ilk modernleşme çabalarının olduğu Tanzimat döneminde tartışılmaya başlanmış (Er 2008: 28) ve ilk örnekler de yine bu dönemde ortaya çıkmıştır. Bunlar arasında 1873 'te bir kadının ilk defa öğretmen olarak atanması, 1881'de okul töreninde bir kadının ilk defa kamusal alanda konuşma yapması ve nihayet 1883 'te okullara kadınların yönetici olarak atanması (Kodaman 1980: 266) gibi örneklerle gelişmeye devam etmiştir. Türk akademik hayatında Türk kadınına yükseköğrenim yapma olanağı ilk kez Meşrutiyet Dönemi'nde sağlanmıştır (Kurnaz 1996). Cumhuriyet Dönemi'nde Medeniyet Projesi kapsamında modern kadın kurgusu oluşturulmuş ve "eğitim" aracılığıyla bu proje kentlerde uygulanmaya çalışılmıştır (Er 2008). Cumhuriyet Dönemi'ne geçildiğinde de kadınlar yükseköğrenime kabul edilme haklarını kullanarak, akademik ilerlemeler yapmışlardır (Çağlayan 2015).

Akademik yaşamda kadınların geleneksel olarak ev işleri, çocuk bakımı gibi rutin rolleri yanında; ders anlatma, bilimsel araştırma yapma, kitap, makale yazma, kongre-konferans gibi etkinliklere katılma gibi mesleki sorumluluklarının olması akademide kadınların iş ve aile hayatlarını zorlaştıran bir unsur olmaktadır (Başarır ve Sarı 2015).

Bu kapsamda makalede Türk yükseköğretimi turizm bilim alanında çalışan kadın akademisyenlerin mevcut durumunun saptanması ve akademik performanslarının ortaya çıkarılması hedeflenmiştir. Bu doğrultuda yürütülen araştırmada ortaya konulan verilerle turizm bilim alanında kadın akademisyenler çeşitli dinamiklerle (unvanlarına göre dağılımı, yayın türlerine göre dağılımları, yürüttükleri lisansüstü tez yöneticiliği vb.) ele alınıp incelenecektir.

\section{ALANYAZIN TARAMASI}

Kadın akademisyen çalışmaları (Spuler 1975; Ergün 1978; Öncü 1979; Acar 1983, 1989, 1990a, 1990b, 1991, 1996, 1998; Köker 1988; Cindoğdu ve Muradoğlu 1996; Kurnaz 1996; Şenesen 1996; Er 2008) 1979 yılından itibaren dikkat çeken bir konudur. Türkiye'de ilk kadın konulu çalışma Köker'e (1988) ait “Türkiye'de Kadın, Eğitim ve Siyaset: Yüksek Öğretim Kurumlarında Kadının Durumu Üzerine Bir İnceleme" başlıklı doktora tezidir. Bu çalışmada 21 kadın akademisyenle derinlemesine görüşme yapılarak veriler toplanmıştır. Meslek bilinci, gündelik yaşamlarını sürdürme, bilim, ilerleme, aydın ve siyaset konuları üzerine kadın akademisyenlerin görüşleri alınmıştır. Kadın akademisyenlerin toplumda kendilerine yüklenen görevlerdeki hak ve sorumlulukları zihinlerinde ne derece içselleştirdikleri, bu ortamda kendilerini nasıl konumlandırdıkları incelenmiştir. Bu çalışmadan sonra da kadın konulu çalışmalara sıkça rastlanmaya başlanmıştır. Son dönemlerde yapılan bir başka çalışma ise kadin akademisyenlerin durumunu sosyolojik bir yaklaşımla inceleyen bir diğer doktora tezidir (Er 2008). Araştırma sonucunda; kadın öğretim 
üyelerinin çoğunluğunun unvanları yükseldikçe taşra üniversitelerindeki oranlarının düştüğü, toplumsal cinsiyet bağlamında unvanlarına göre belirli alanlarda yoğunlaştıkları, orta ve üst idari pozisyonlarda daha düşük sayıda temsil edildikleri; akademik unvan basamaklarında terfi ve ilerleme hususunda düşük oranda cinsiyet ayrımcılığıyla karşılaştıkları saptanmıştır. Köker'in (1988) üniversitelerde kadın akademisyenleri ele aldığ 1 çalışmadan 20 yıl sonra gerçekleştirilen ve sosyolojik bir yaklaşımla ele alınan çalışmada kadın akademisyenlerin ücret, iş tatmini, bilimsel çalışmalar, cinsel taciz, siyasete katılım, din, moda ve boş zamanları değerlendirme gibi konularda görüşleri alınmıştır. Bu çalışma sonucunda da Köker (1988) ve Acar'ın (1996) çalışmaları ile demografik özellikler açısından örtüşen sonuçlar elde edilmiștir. Örneğin, kadın öğretim üyelerinin kent kökenli olması, gelir düzeyi açısından orta ve orta sınıfın üstü seviyesinden gelmesi gibi. Kadın öğretim üyelerinin özel ve iş yaşamlarında geleneksel konumlarının geçerliliğini koruduğu, idari görevlerde orta ve üst seviyelerde düşük oranlarda yer aldıkları saptanmıştır.

Kadınların akademik yaşamdaki mevcut durumları, kadınların akademiye girişini ortaya koymaya yönelik betimsel çalışmalar da (Acar 1996; Akbulut 2011) mevcuttur. Erkek akademisyenlerin kadın akademisyenlerle kurdukları sosyal ilişkileri, kadın akademisyenleri konumlandırmalarını ve aralarındaki bilgi alışverişini belirlemeyi amaçlayan bir çalışmada da erkek akademisyenlerin toplumsal cinsiyetlere göre bir ayrımda bulundukları sonucuna ulaşılmıştır (Altınoluk 2017).

Kadın akademisyenlerin "kadın akademisyen" olmaya yönelik algılarını metaforlar yoluyla inceleyen nitel bir çalışmada, kadın akademisyenlerin en fazla "çoklu görev ve sorumluluklara sahip" ve "ürettikleriyle etrafını besleyen biri" şeklinde kavramsal kategorilerle kendilerini ifade ettikleri saptanmıştır (Başarır ve Sarı 2015). Batman Üniversitesi'nde kadın akademisyenlerin karşılaştıkları sorunların incelendiği bir çalışmada ise evliliğin akademik kariyeri engellediğini ve çocuk sahibi olmanın akademik ilerlemeyi olumsuz etkilediğini düşündüklerini belirlemiş- lerdir. Kadın akademisyenler cinsiyete dayalı bir eşitsizlik yaşamadıklarını ve akademik kariyer yaşamında eş desteğinin önemli olduğunu ifade etmişlerdir (Çakır ve Arslan 2018). Bu iki çalışmada da kadın akademisyenlerin kendileri ile ilgili algıları ve sorunları incelenmiştir.

Turizm bilim alanında çalışan kadın akademisyenlerin işyeri arkadaşlıklarının örgüt iklimine ve bu arkadaşlıkların kadın akademisyenlerin yaşamlarına etkisini inceleyen başka bir çalışmada ise bölüm başkanlığı görevi olan kadın akademisyenlerin işyeri arkadaşlıklarından bireysel ve profesyonel olarak etkilendiklerini, kadın çalışan ve yöneticilere karşı algılarının olumlu olduğu saptanmıştır (Kozan Akbayırlı 2016). Turizm alanında kadın akademisyenlerle yürütülen tek çalışma olan bu yüksek lisans tezinde kadın akademisyenlerin işyeri arkadaşlıklarının örgüt iklimine etkisi incelenmiştir.

Naymansoy (2009) tarafından yürütülen doktora tez çalışmasında ise Türkiye Bilimler Akademisi (TÜBA) ve Türkiye Bilimsel ve Teknolojik Araştırma Kurumu (TÜBİTAK) Bilim, Hizmet ve Teşvik Ödüllerini alan bilim insanları ile sınırlandırılarak Türk bilim kadınları inceleme konusu yapılmıştır. Sağlık (40 akademisyen), sosyal bilimler (27 akademisyen), temel bilimler (25 akademisyen), mühendislik ve mimarlik (19 akademisyen) alanlarındaki kadın akademisyenlerin biyografileri incelenmiş ve ayrıca görüşmelerle veriler elde edilmiştir. Kadın akademisyenlerin oranının istatistiksel olarak en yüksek olduğu alan mimarlık iken sayısal olarak sağlık alanında yoğunlaşmıştır. Ayrıca, aldıkları ödüller açısından değerlendirildiğinde de Türk kadın akademisyenlerin en fazla etkin olduğu alan sağlık bilimleridir. Sosyal bilimlerin oranının düşük olması ise ödüllendirmelerde sosyal bilimlerde bilim ödüllerinin 2008 yılından itibaren verilmeye başlanması ile açıklanmıştır.

Uluslararası ilişkiler disiplininde kadın akademisyenlerin disiplin alanlarının eril bir yapıya sahip olup olmadığıyla ilgili düşünceleri inceleyen bir çalışmada; kadın akademisyenler akademide eril bir yapının var olduğunu düşünmekle beraber, genç nesilde erilleşmeye karşı bir tavır olduğunu tespit etmişlerdir (Öner ve Özdemirkıran 2017). 
Türkiye'de kadın akademisyenlerin mesleklerine karşı tutumları ile akademik ilerlemede ve yöneticiliğe atanmada cinsiyetin etkisi (Özkanlı ve Korkmaz 2000), meslek yüksekokullarında teknik bilimler alanındaki kadın akademisyen oranları (Şevik 2016), yönetim kadrolarında kadın akademisyenlerin cam tavan engelini (Tahtalığlu 2016) inceleyen araştırmalar da mevcuttur.

Tepe (2018) kadın akademisyenlerin işte ve evde yerine getirmeleri gereken rollerinden dolayı çifte vardiya yaptıklarını ve bu durumu rol çatışması $\mathrm{m}$ rol genişlemesi olarak $\mathrm{m}$ deneyimlediklerini incelemiştir. Fen bilimleri alanındaki kadın akademisyenlerle derinlemesine görüşme yöntemi kullanılarak yürütülmüştür. Çalışma sonucunda kadın akademisyenlerin çoğunluğunun çifte vardiyayı rol çatışması olarak deneyimlediği tespit edilmiştir. Kadın akademisyenlerin Türkiye'de ücret dağılımları inceleyen bir çalışmada ise kadın akademisyenlerin daha düşük ücret aldıkları ortaya konmuştur (Ucal vd. 2015).

Köker'in (1988) çalışması üzerinden geçen yaklaşık 20 yıllık zaman diliminde kadın akademisyenlerin ücret seviyeleri, cam tavan sendromları, iş tatmini, rol çatışması, yönetim kademesinde kadın akademisyenlerin oranı gibi farklı konularda çalışmalar yürütülmüştür. Modernleşme sürecinde toplumun en üst eğitim kurumunda görev yapan kadın akademisyenler için de geleneksel toplumsal roller geçerliliği devam ettirirken, iş yaşamının erkek egemen özelliğinin olması ve kadın akademisyenlerin aile ve iş yaşamını dengelemede sorunlarının olduğu yapılan çalışmalarla da ortaya konmuştur.

\section{YÜKSEKÖĞRENIM DÜZEYINDE TURIZM EĞiTiMi}

Türkiye'de turizm eğitimi ve öğretimi ile ilgili çalışmalarda (Korzay 1987; Ünlüönen 1993; Brotherton vd. 1994; Okumuş ve Yağc1 2005; Ünlüönen ve Boylu 2005; Yeşiltaş vd. 2010) konuların çoğunlukla planlı dönem öncesi ve planlı dönem gelişmeleri olarak iki aşamaya ayrılarak ele alındığı görülmektedir. Planlı dönem öncesinde Osmanlı İmparatorluğu döneminde 1863 yılında Sergi-i Umumi-i Osmani (Osmanlı Genel Sergisi) düzenlenen ilk iç turizm etkinliği olarak kayıtlarda yer almıştır (Kozak vd. 2017: 145). Yurtdı- şından gelen turistlere hizmet verecek rehberler ile ilgili 1890 yılında yürürlüğe giren Seyyahine Tercümanlık Edenler Hakkında Tatbik Edilecek 190 Sayılı Nizamname ile yasal düzenlemelerle bu süreç devam etmiştir (Akpınar 2006: 2). Cumhuriyet döneminde ise 1925 yılında 1730 sayılı Seyyah Tercümanları Hakkında Kararname çıkarılarak bir yönetmelik düzenlenmiştir ve sonrasında turist rehberliği ve meslek kursları ile turizm gelişimi devam etmiştir (Ünlüönen 1993:499).

Korzay (1994), Türkiye'de turizmin gelişimini farkındalık (1955-1970), teşvik yılları (1970-1982) ve eylem (1982 yılından bugüne) dönemi şeklinde üçe ayırarak incelemiştir. Korzay'ın bu yaklaşımında turizm eğitimi açısından ilk dönemin önemli olaylarından biri 1961 yılında Ankara Otelcilik Okulu'nun açılmasıdır. Ankara Otelcilik Okulu, turizmin ekonomik açıdan bir çıkış yolu olarak görülerek, sektörde hizmet verecek nitelikli personelin yetişmesi konusunda açılan ilk okul özelliği taşımaktadır (Toker 2018: 565).

Yükseköğretimde önlisans düzeyinde ilk turizm eğitimi veren bölümler 1970'li yılların başında Boğaziçi Üniversitesi ve Ege Üniversitesi bünyesinde (Ünlüönen 1993), daha sonra Hacettepe Üniversitesi'nde (Kozak 2000) açılmıştır. Bu okulların bir bölümü daha sonra lisans düzeyinde eğitim vermeye devam etmiş, bu okullara ilave olarak 1976 yılında Balıkesir (Gülenç 2018) ve 1979 yılında Mersin'de (Evren 2018) turizm lisans okulları eğitime başlamıştır.

Yükseköğretim Kurulu'na bağlı olarak turizm ve otel işletmeciliği eğitimi hiyerarşik olarak dört aşamada verilen bir eğitimdir. Bunlar:

- Önlisans düzeyinde iki yıllık meslek yüksekokulları,

- Lisans düzeyinde dört yıllık turizm fakülteleri veya turizm işletmeciliği ve otelcilik yüksekokulları,

- Sosyal bilimler enstitülerine bağlı olarak eğitim veren turizm ve ilgili diğer yüksek lisans programlar1,

- Sosyal bilimler enstitülerine bağlı olarak eğitim veren turizm işletmeciliği doktora programlarıdır. 
Yükseköğrenim düzeyinde yaşanan bu hızlı değişimin arka planında sektördeki gelişmelerin rol oynadığ 1 ifade edilebilir. Okumuş ve Yağc1 (2005), Türk turizminin 1980'li yılların başından itibaren hızlı bir gelişme ivmesi yakaladığını vurgulamaktadır. Özellikle 1982 yılında çıkarılan Turizmi Teşvik Kanunu ile bu ivme hız kazanarak devlet desteğinin finansal ve hukuki anlamda sağlanması sonucunda tesis sayısında da artış yaşanmıştır. Bununla ilgili veriler incelendiğinde Türkiye'de turizm işletme ve yatırım belgeli konaklama tesisleri 1970 yılında 54.226 yatak kapasitesine sahip iken 1980 yılında 82.332'ye yükselmiş, 1990 yılında ise 325.515 yatak kapasitesine ulaşmıştır (Kültür ve Turizm Bakanlığ1 2019). 2019 yılında ise turizm işletme belgeli tesislerde yatak kapasitesi 974.991'e yükselmiştir (tursab. org.tr).

Açlan tesislerdeki eleman ihtiyacının önlisans ve lisans düzeyinde okulların açılması ile karş1lanması hedeflenmiştir. Yükseköğretim düzeyinde eğitim veren kurumların nitelikleri 2547 Sayılı Yükseköğretim Kanunu 3. Maddesinde şöyle ifade edilmiştir (2547 Sayılı Yükseköğretim Kanunu):

- Fakülte: Yüksek düzeyde eğitim-öğretim, bilimsel araştırma ve yayın yapan; kendisine birimler bağlanabilen bir yükseköğretim kurumudur.

- Yüksekokul: Belirli bir mesleğe yönelik eğitim öğretime ağırlık veren bir yükseköğretim kurumudur.

- Meslek Yüksekokulu: Belirli mesleklere yönelik nitelikli insan gücü yetiştirmeyi amaçlayan yılda iki veya üç dönem olmak üzere iki yıllık eğitim- öğretim sürdüren, önlisans derecesi veren bir yükseköğretim kurumudur.

Boyacı ve Aktaş (1995), Türkiye'de 1995 yılında lisans düzeyinde turizm eğitimi veren 10 adet turizm işletmeciliği ve otelcilik yüksekokulu bulunduğunu ifade etmiştir. Akoğlan Kozak (2009) ise 15'i İktisadi ve İdari Bilimler Fakülteleri'nin bünyesinde, altısı Uygulamalı Bilimler Yüksekokulu bünyesinde ve 22'si Turizm İşletmeciliği ve Otelcilik Yüksekokulu olarak faaliyet gösteren 43 kurumda lisans düzeyinde turizm eğitimi veril- diğini vurgulamıştır. Günümüzde ise üniversitelerde sadece turizm fakültesi sayısının 45'e ulaştığı saptanmıştır (YÖK İstatistikleri).

İzmir İktisadi ve Ticari İlimler Akademisi'ne bağlı olarak 1964 yılında Turizm Enstitüsü kurulmuş, daha sonraki yıllarda Ege Üniversitesi İşletme Fakültesi Turizm İşletmeciliği Bölümü'nde 1982-1983 öğretim yılına kadar turizm işletmeciliği dalında yüksek lisans ve doktora programlarında eğitimlere devam etmiştir (Ünlüönen 1993). İlk doktora programı ise 1972 yılında İstanbul Üniversitesi bünyesinde açılmıştır (Yeşiltaş vd. 2010). Daha sonraki y1llarda Hacettepe ve İstanbul Üniversitesi de lisansüstü eğitim veren kurumlar arasına eklenmiştir (Ünlüönen ve Boylu 2005). Günümüzde turizm alanında yüksek lisans programı sayıs 80, doktora düzeyinde ise 50’yi aşmaktadır (Kozak ve Kozak 2018: 7). Solmaz ve Ulema (2014) 2013 yılında yükseköğretim istatistikleri verilerine göre Türkiye'de önlisans ve lisans düzeyinde turizm eğitimi veren öğretim elemanları sayısını 814 olarak ifade etmiştir.

Türk turizm literatürünün gelişim evrelerini 1940-1990 yılları arasını Birinci Dönem, 1991-2010 yılları arasını Íkinci Dönem ve 2011-2018 aras1$\mathrm{n} 1$ ise Üçüncü Dönem şeklinde sınıflandırılmıştır (Kozak ve Kozak 2018). Birinci Dönem, farklı disiplinlerden gelen özellikle de ekonomi, pazarlama, coğrafya, sosyoloji gibi farklı alanlardan gelen ve turizme odaklanan akademisyenlerin olduğu bir dönemdir (Kozak ve Kozak 2018: 4). Turizm literatürünün İkinci Dönemi'nde turizm alanında lisansüstü eğitimini tamamlayan akademisyenlerin turizm okullarında görev aldığ 1 bir dönem olarak karşımıza çıkmaktadır. Ayrıca, turizm doçentlik bilim alanı arasından çıkarılmıştır. Bu dönemin akademisyenlerinin turizmi bir uygulama alanı olarak ele alarak, pazarlama, ekonomi, yönetim gibi alanlarda uzmanlaştığ 1 bir dönem olmuştur. Son dönemde ise alınan bir kararla turizm tekrar doçentlikte bilim alanı olarak kabul edilmiştir (Kozak ve Kozak 2018).

Öğretim üyeliğinden emekli olan Meral Korzay, Şule Çetin ve Bahar Taner gibi kadın akademisyenlerimiz, turizm literatürüne önemli katkılarda bulunmuştur. Korzay, 1970 yılında Ege Üniversitesi'nde İzmir'i ziyaret eden turist- 
lere ilişkin pazarlama psikolojisi konulu tezi ile doktora derecesi alarak, 1976 yılında doçent, 1984 yılında profesör unvanı almıştır. Akademik kariyerine Ege Üniversitesi'nde başlamış, ardından Boğaziçi Üniversitesi Turizm İşletmeciliği Bölümü'nde devam etmiş ve bu bölümden 2004 yılında emekli olmuştur (Alvarez 2018: 266).

Turizme önemli katkılar vermiş olan kadın akademisyenlerimizden bir diğeri Çukurova Üniversitesi Mersin Turizm İşletmeciliği ve Otelcilik Yüksekokulu öğretim elemanı olarak görev yapan ve 2008 yılında emekli olan Şule Çetin'dir. Çetin, Gazi Üniversitesi Ticaret ve Turizm Yüksek Öğretmen Okulu mezunudur. Turizm eğitimi, turizm sektöründe çalışacak elemanlara yönelik eğitim programları ve istihdam sorunları gibi konularda çalışmaları ile önemli katkılarda bulunmuştur (Sahilli Birdir 2018). Bu iki değerli kadın akademisyenimiz dışında turizm bilim alanına katkıda bulunan ve halen akademik çalışma hayatına devam eden kadın akademisyenlerimizi de tespit etmeye yönelik bu çalışmada kadın akademisyenlerimizin mevcut durumunun saptanması hedeflenmiştir. Çalışmanın literatüre bu yönüyle de katkı sağlayacağı düşünülmektedir.

\section{YÖNTEM}

Bu çalışma, Türkiye'de yükseköğretimde turizm alanında görev yapan kadın öğretim elemanlarının (öğretim üyeleri, öğretim görevlileri ve araştırma görevlilerinin) mevcut durumunu ortaya koymayı amaçlamaktadır. Bu temel amaç çerçevesinde araştırma sürecinde aşağıdaki sorulara yanıt aranmıştır:

- Turizm alanında kadın öğretim elemanı sayısı nedir?

- Kadın öğretim elemanlarının unvanlarına göre dağılımı nedir?

- Kadın öğretim elemanlarının üniversitelere göre dağılımı nedir?

- Kadın öğretim elemanlarının akademik çalışmalarının dağılımı nedir?

$\mathrm{Bu}$ araştırma, betimsel araştırma tasarımı ile şekillenmiş ve https://akademik.yok.gov.tr adresi veri toplama sitesi olarak belirlenmiştir. $\mathrm{Bu}$ doğrultuda verilerin toplanmasında belgesel kaynak tarama tekniği (doküman incelemesi) kullanılmıştır. "Belgesel kaynak tarama, araştırılan konu hakkında diğer kişi veya kurumlar tarafından yazılmış, hazırlanmış veya yaratılmış çeşitli yazı, belge, yapım veya kalıntının toplanması ve incelenmesi" dir (Seyidoğlu 1995: 36).

Bu amaçla, doküman (belgesel kaynak tarama) incelemesinin aşamaları; dokümanlara ulaşma, özgünlüğün kontrolü, dokümanı anlama, veriyi analiz etme, veriyi kullanma olarak kurgulanmıştır (Yıldırım ve Şimşek 2006: 193). Yükseköğretim Kurulu Başkanlığı'nın "Akademik Arama (akademik.yok.gov.tr)" sayfasındaki veriler, yükseköğretim kurumlarının idari kayıtlarına dayalı olarak yükseköğretim kurumlarında görev yapan öğretim elemanlarının Yükseköğretim Bilgi Yönetimi Sistemi (YÖKSİS) üzerindeki kayıtlarının akademik.yok.gov.tr adresine aktarılması ile oluşturulmaktadır. Çalışmada bu veriler esas alınmıştır.

Türkiye'deki üniversitelerde çalışan kadın akademisyenler bu araştırmanın evrenini oluşturmaktadır. Araştırmada, yükseköğretim kurumlarında turizm bilim alanında görev yapan kadın öğretim elemanlarına ait belgesel tarama yöntemi ile elde edilen verilerin çeşitli özellikleri frekansları ile özetlenerek yorumlanmıştır. Araştırmada betimsel analiz tekniği kullanılarak veriler araştırma soruları çerçevesinde unvan, görev yaptıkları üniversite, akademik çalışmaları ise yayınlanan kitap, makale, bildiri, proje ve yönetilen tezler açısından incelenerek analiz edilmiştir. Kadın akademisyenlerin farklı değişkenler açısından karşılaştırılmasında varyans analizinden yararlanılmıştır. Varyans analizi sonucunda fark bulunan grubu belirlemek amacı ile çeşitli testlerden yararlanılmıştır.

\section{BULGULAR}

Bu bölümde araştırma kapsamında elde edilen bulgular, araştırma soruları çerçevesinde sunulmuş ve yorumlanmıştır. Araştırma verileri 1 Temmuz 2018 ile 20 Mart 2019 tarihleri arasinda toplanmıştır. Bu tarihler arasında sistemde değişiklik yapan öğretim elemanlarının bilgilerinde farklılıklar ortaya çıkabilmektedir. Elde edilen 
Tablo 1. Turizm Bilim Alanında Görev Yapan Öğretim Elemanları

\begin{tabular}{lrr}
\hline Cinsiyet & Sayı & $\%$ \\
\hline Kadın & 486 & 40,17 \\
\hline Erkek & 724 & 59,83 \\
\hline TOPLAM & 1210 & 100,00 \\
\hline
\end{tabular}

verilerin sunulmasında, araştırma sonuçlarını çalışma kapsamında özetlemek ve araştırmanın bütünü hakkında bilgilendirmek amaciyla sadece özet bilgilere yer verilmesi uygun görülmüştür.

Araştırma sorularından birincisini oluşturan "Turizm alanında kadın öğretim elemanı sayısı nedir?" sorusuna ilişkin bulgular Tablo 1'de gösterilmiştir. Buna göre, sosyal, beşeri ve idari bilimler alanı turizm bilim alanında görev yapan akademisyenlerin içinde kadın akademisyen oranı erkeklere oranla \%40,17'dir. Diğer bir deyişle; turizm bilim alanında görev yapan 1210 akademisyenden 486 'sı $(\% 40,17)$ kadınlardan oluşurken, geri kalan $724^{\prime}$ ü $(\% 59,83)$ ise erkektir.

Tablo 2, turizm bilim alanında görev yapan tüm akademisyenlerin unvanlarına ve görev yaptıkları üniversitenin devlet veya vakıf üniversitesi olmasına göre dağılımlarını göstermektedir. Kadın akademisyenler içinde \%31,7 ile öğretim görevlisi unvanına sahip iken, en düşük orana profesör unvanına sahip akademisyenler takip etmektedir.
Kadın akademisyenlerin görev yaptığı üniversite türüne ilişkin bilgiler incelendiğinde akademisyenlerin büyük bir kısmının $(\% 86,63)$ devlet üniversitesinde görev yaptığı saptanmıştır. Vakıf üniversitesinde görev yapanlar içinde ise en yüksek oranı öğretim görevlisi unvanındaki akademisyenlerin oluşturduğu tespit edilmiştir.

Kadın akademisyenlerin çalışma konularına ilişkin kendilerinin tanımladığı anahtar kelimeleri gösteren dağılıma Tablo 3'te yer verilmiştir. $\mathrm{Bu}$ tabloda en az kullanılan anahtar kelimenin gastronomi olduğu dikkat çekmektedir. Bu anahtar kelimenin sisteme yeni tanımlanmış olması dolayısıyla, kullanım oranının düşük olduğu ifade edilebilir.

Turizm bilim alanında kadın akademisyenlerin lisansüstü tez danışmanlıklarına ilişkin veriler ise Tablo 4'te sunulmuştur.

Doktora tez danışmanlığında doçent unvanlı akademisyenler, yüksek lisans tez danışmanlığında ise doktor öğretim üyesi unvanına sahip akademisyenlerin en fazla oranda danışmanlık görevi üstlendiği tespit edilmiştir.

Kadın akademisyenlerin yayınları ile unvanları arasında anlamlı farklılık olup olmadığı test edilmiştir. Burada, kadın akademisyenlerin kitap, makale, bildiri ve proje değişkenlerine göre unvanlarının farklılık gösterip göstermediği incelenmiştir. Veriler normal dağılım göstermediğinden, burada Kruskal Wallis $\mathrm{H}$ analizinden yararlanılmıştır. İstatistiksel analizlerin tümü \%95 güvenilirlik düzeyinde yapılmıştır.

Tablo 2. Turizm Bilim Alanında Görev Yapan Akademisyenlerin Unvanlarına ve Görev Yaptıkları Üniversite Türlerine Göre Dağılımı

\begin{tabular}{lcccccr}
\hline Unvan & \multicolumn{3}{c}{ Kadın } & \multicolumn{3}{c}{ Üniversite Türü } \\
\hline & Sayı & $\%$ & $n$ & & Vakıf \\
\hline Profesör & 17 & 3,5 & 17 & 100,00 & & Devlet \\
\hline Doçent & 31 & 6,4 & 29 & 93,5 & 2 & - \\
\hline Dr. Öğr. Üyesi & 148 & 30,5 & 130 & 88,8 & 18 & 12,2 \\
\hline Öğretim Görevlisi & 154 & 31,7 & 117 & 75,97 & 37 & 24,03 \\
\hline Araştırma Görevlisi & 136 & 28,0 & 128 & 94,12 & 8 & 5,88 \\
\hline TOPLAM & 486 & 100,00 & 421 & 86,63 & 65 & 13,37 \\
\hline
\end{tabular}


Tablo 3. Turizm Bilim Alanında Görev Yapan Akademisyenlerin Çalışma Konularında Tanımladıkları Anahtar Kelimelere Göre Dağılımı

\begin{tabular}{lcr}
\hline Anahtar Kelime & Sayı & $\%$ \\
\hline Turizm İşletmeciliği & 340 & 70,0 \\
\hline Otel İşletmeciliği & 49 & 10,1 \\
\hline Turizm Pazarlaması & 54 & 11,1 \\
\hline Turizm Ekonomisi & 12 & 2,5 \\
\hline Sürdürülebilir Turizm & 26 & 5,3 \\
\hline Turizm Planlaması & 3 & 0,6 \\
\hline Gastronomi & 2 & 0,4 \\
\hline TOPLAM & 486 & 100,00 \\
\hline
\end{tabular}

Kadın akademisyenlerin unvanlarına göre yayın türleri açısından anlamlı farklılık bulunmaktadır. Buna göre kitap, makale, bildiri ve proje puanları en yüksek olanlar profesör doktor unvanına sahip kadın akademisyenler iken, öğretim görevlisi unvanına sahip kadın akademisyenler en düșük sıra ortalamasına sahiptir. Profesör un-
Tablo 4. Turizm Bilim Alanında Görev Yapan Akademisyenlerin Lisansüstü Tez Danışmanlıklarına Göre Dağılımı

\begin{tabular}{|c|c|c|c|c|}
\hline \multirow[t]{2}{*}{ Anahtar Sözcük } & \multicolumn{2}{|c|}{$\begin{array}{c}\text { Doktora Tez } \\
\text { Danışmanlığı }\end{array}$} & \multicolumn{2}{|c|}{$\begin{array}{r}\text { Yüksek Lisans Tez } \\
\text { Danışmanlığı }\end{array}$} \\
\hline & $\mathrm{n}$ & $\%$ & $n$ & $\%$ \\
\hline Prof. Dr. & 11 & 35,48 & 15 & 15 \\
\hline Doç. Dr. & 13 & 41,94 & 28 & 28 \\
\hline Dr. Öğr. Üyesi & 7 & 22,58 & 57 & 57 \\
\hline TOPLAM & 31 & 100,00 & 100 & 100,00 \\
\hline
\end{tabular}

vanını, doçent, doktor öğretim üyesi ve araştırma görevlisi unvanına sahip akademisyenler takip etmiştir.

Araştırmada incelenen diğer değişkenler açısından da inceleme yapılmıştır. Ancak, anahtar kelime, üniversite türü gibi değişkenler açısından gruplar arasında anlamlı fark olmadığı görülmüştür. Bu nedenle, anlamlı fark bulunmayan değişkenlere ilişkin sonuçlara çalışmada yer verilmemiştir.

Tablo 5. Kadın Akademisyenlerin Unvan Gruplarının Yayınlarına Göre Karşılaştırması

\begin{tabular}{|c|c|c|c|c|c|}
\hline & Unvanlar & $N$ & Sira Ortalama & $x^{2}$ & Anlamlılık Düzeyi $(P)$ \\
\hline \multirow[t]{5}{*}{ Kitap } & Prof. Dr. & 17 & 427,76 & 147,740 & , $000 *$ \\
\hline & Doç. Dr. & 31 & 399,82 & & \\
\hline & Dr. Öğr. Üyesi & 147 & 297,33 & & \\
\hline & Öğr. Gör. & 158 & 170,26 & & \\
\hline & Arş.Gör. & 136 & 209,19 & & \\
\hline \multirow[t]{5}{*}{ Makale } & Prof. Dr. & 17 & 458,21 & 199,736 & ,000* \\
\hline & Doç. Dr. & 31 & 422,76 & & \\
\hline & Dr. Öğr. Üyesi & 147 & 314,35 & & \\
\hline & Öğr. Gör. & 158 & 163,58 & & \\
\hline & Arş.Gör. & 136 & 189,19 & & \\
\hline \multirow[t]{5}{*}{ Bildiri } & Prof. Dr. & 17 & 374,53 & 113,350 &, $000 *$ \\
\hline & Doç. Dr. & 31 & 389,21 & & \\
\hline & Dr. Öğr. Üyesi & 147 & 299,58 & & \\
\hline & Öğr. Gör. & 158 & 163,58 & & \\
\hline & Arş.Gör. & 136 & 189,19 & & \\
\hline
\end{tabular}




\section{SONUÇ}

Türkiye'de turizm bilim alanında kadın akademisyenleri "resmetmeyi" amaçlayan bu çalışma, kadın akademisyen profilini sunmaktadır. Araştırma bu alanda görev yapan akademisyenlere ilişkin elde edilen sayısal veriler turizm akademisinde kadınların varlığını ortaya koyan bir ön çalışma olarak görülmelidir. Turizm bilim alanında kadın akademisyenlerin unvanları, yayın türleri, görev yaptıkları üniversite türü, yürüttükleri lisansüstü tez danışmanlıkları gibi değişkenler açısından mevcut durum ortaya konmuştur. Bu tablo, Türkiye'de yükseköğrenim düzeyinde turizm eğitiminde kadınların bulunduğu yeri ifade etmektedir. Tüm akademisyenler içinde kadınların \%40 gibi bir orana sahip olması turizm eğitim ihtiyacını karşılamada kadınların da önemli rol üstlendiğini göstermesi bakımından önemlidir.

Yükseköğretimde turizm bilim alanında, kadın akademisyenlerin durumunu belirlemeyi amaçlayan bu çalışmadan elde edilen bulgulara dayanarak, şunları söylemek mümkündür:

- Kadın akademisyenlerin turizmde en fazla öğretim görevlisi ve doktor öğretim üyesi unvanına, en düşük oranda da profesör unvanına sahip oldukları saptanmıştır. Bu durum, önlisans düzeyinde okul sayısının lisans düzeyinde okul sayısına göre daha fazla olması ile açıklanabilir.

- Turizm bilim alanında kadın akademisyenlerin en fazla devlet üniversitesinde görev yaptıkları saptanmıştır. Araştırma sonuçlarına bağlı olarak, kadın akademisyenlere ilişkin bu tablonun zaman içinde değişeceğini söylemek mümkündür. Turizm alanında doktora eğitiminin 1970'li yıllardan itibaren verilmesi nedeni ile ilerleyen yıllarda bu tür çalışmaların zaman karşılaştırmalarının yapılarak daha gerçekçi sonuçların ortaya çıkması sağlanabilir. Bu çalışmada karşımıza çıkan unvanlar arasındaki sayı farklılığı zaman içinde azalacağından, her bir unvana göre farklı değişkenleri karşılaştırırken her bir unvanın ayrı ayrı dikkate alınması gerekmektedir.
Önceki araştırmalarda çoğunlukla turizm eğitiminin durumu, sorunları gibi konular incelenirken, bu çalışmada ilk kez eğitim veren kişiler inceleme konusu olmuştur. Yükseköğretim alanında görev yapan akademisyenler için oluşturulan resmi sitedeki bilgilerden yararlanılarak, turizm eğitiminde kadın akademisyenlerin durumu sunulmuştur. Tarafsız ve kişilerin kendi veri girişini yaptıkları bir sayfadan verilerin elde edilmiş olması da çalışmanın güvenilirlik düzeyini artırmaktadır. Bu çalışmada, tarafsız bir şekilde veriler elde edilerek, karşılaştırma yapılmış ve veriler değerlendirilmiştir. Konuyla ilgili olarak, daha önce bu tür bir çalışmanın olmaması, söz konusu bu çalışmanın literatüre yaptığı bir katkı olarak ifade edilebilir. Bununla birlikte; araştırmada, sadece nicel olarak değerlendirmelerde bulunulmuştur. Bunun yanında, kadın akademisyenlerin çalışmalarının niteliksel özelliklerinin de ayrı bir araştırma konusu olarak ele alınması gerekmektedir.

Çalışmanın sadece belirli değişkenler açısından ele alınması araştırmanın en önemli kısıtını oluşturmaktadır. Dolayısıyla, turizm bilim alanında kadın akademisyenlerin sadece unvan, görev yapılan üniversite türü, yayın türleri ve danışmanlıklar gibi bazı sayısal veriler üzerinden yürütülmesi niteliksel değerlendirmelerin yapılmasını engellemiştir.

Sonuç olarak; turizmin giderek büyüyen bir sektör olması ve artan turist sayısına ilişkin tesis sayısının da artması bu alanda kalifiye çalışan ihtiyacını karşılamak için yükseköğretimde turizm eğitimi kurumları sayısının artacağına ilişkin beklentiler, akademisyen sayısında da bir gelişme ve artış olacağını ortaya koymaktadır. Yeni eğilimlerle ve değişimlerle ilerleyen turizm sektöründeki bu gelişme ve büyüme sürecindeki en önemli nokta, eğitim alanında da rekabet gücü olgusudur. Eğitim kurumlarının ve akademisyenlerin birer marka haline dönüşmeye başladı̆̆g eğitim camiasında küresel açıdan da kaliteli bilimsel yayınlara ve çalışmalara sahip olan akademisyenlerin gelecekte daha başarılı olacakları ve rekabetçi üstünlük sağlayarak, sektöre de yön verecekleri beklenmektedir. 


\section{KAYNAKÇA}

Acar, F. (1991). Women in Academic Science Careers in Turkey. İçinde V. S. Heiskanen (Editör), Women in Science Taken Women or Gender Equality (ss.147-171). New York: St Martin's Press.

Acar, F. (1996). Türkiye'de Kadın Akademisyenler: Tarihsel Evrim ve Bugünkü Durum. İçinde H. Coşkun (Editör), Akademik Yaşamda Kadın (ss. 75-102), Ankara: TürkAlman Kültür İşleri Kurulu Yayın Dizisi No. 9.

Acar, F. (1998). Türkiye Üniversitelerinde Kadın Öğretim Üyeleri, 75 Yılda Kadınlar ve Erkekler. İstanbul: Türkiye İş Bankasi ve Tarih Vakf1 Ortak Yayını.

Acar, F. (1983). Turkish Women in Academia: Roles and Careers, METU Studies in Development, 10 (4): 409- 446.

Acar, F. (1989). Women's Participation in Academic Science Careers: Turkey in 1989, Improving Prospects for Women in Changing Society: The Years Ahead International Conference, İstanbul.

Acar, F. (1990a). Role Priorities and Career Patterns: A CrossCultural Study of Turkish and Jordanian University Teachers. İçinde S. Hie ve V. O. Learyu (Derleyenler), Storming the Tower Women in Academic World, Londra: Kopan Page.

Acar, F. (1990b). Türkiye'de Kadınların Akademik Kariyere Katılımı. Değişen Bir Toplumda Kadınların İstihdam İmkanlarının Geliştirilmesi Konferansı (ss.81-100). Ankara: İş ve İşçi Bulma Kurumu Yayını.

Acker, J. (1992). From Sex Roles to Gendered Institutions, Contemporary Sociology, 21(5): 565-569.

Adaçay, F. R. (2014). Toplumsal Cinsiyet ve Kalkınma. Bursa: Ekin Yayınevi.

Adak, N. (2018). Akademide Kadınlar: Yükseköğrenime Giriş ve Kariyerde İlerleme, Akdeniz Kadın Çalışmaları ve Toplumsal Cinsiyet Dergisi, 1 (1): 23-38.

Akbulut, N. (2011). Ayna Benlik: Kadın Akademisyenler Gelenekçidir, Eğitim Bilim Toplum Dergisi, 9 (34): 50-66.

Akoğlan Kozak, M. (2009). Akademik Turizm Eğitimi Üzerine Bir Durum Analizi, Muğla Üniversitesi Sosyal Bilimler Enstitüsü Dergisi (İlke), 22: 1-20.

Akpınar, S. (2006). Türkiye'nin Turizm Merkezlerinde Ekoturizm Yaklaşımları, http://www.geocities.com/ceteris_tr/s_ akpinar.doc. Erişim tarihi: 10 Eylül 2018.

Altınoluk, D. (2017). Cinsiyetlendirilmiş Kurum Olarak Akademi: Erkek Akademisyenlerin "Öteki" Üzerinden Erkeklik İnşaları, Masculinities Journal, 8 (Ağustos): 37-58.

Alvarez, M. D. (2018). Meral Korzay Portresi: Türkiye ve Ötesinde Turizmin Gelişmesine Öncülük Etmek. İçinde M. Kozak ve N. Kozak (Editörler), Türk Turizmine Kanat Gerenler Cilt 1 Öncü Turizm Eğitimci ve Araştırmacıları (ss. 265-276). Ankara: Detay Yayıncılık.

Başarır, F. ve Sarı, M. (2015). Kadın Akademisyenlerin “Kadın Akademisyen Olma"ya İlişkin Algılarının Metaforlar Yoluyla İncelenmesi, Yükseköğretim ve Bilim Dergisi, 5 (1): 41-51.

Brotherton, B., Woolfenden, G. ve Himmetoglu, B. (1994). Developing Human Resources for Turkey's Tourism Industry in the 1990s, Tourism Management, 15(2): 109-116.
Boyacı, C. ve Aktaş, A. (1995). Konaklama Sektöründe Ínsangücü Araştırması ve Antalya Örneği, Anatolia: Turizm Araştırmaları Dergisi, 6 (3-4): 48-62.

Cindoğdu, D. ve Muradoğlu, G. (1996). Türkiye'de Tıp Bilimlerinde Kadınların Özgül Durumları. İçinde H. Coşkun (Derleyen.), Akademik Yaşamda Kadın (ss.244-260). Ankara: Türk- Alman Kültür İşleri Yayını.

Çağlayan, K. (2015). Üniversitede Kadın Akademisyenlik, Türkiye Tohumcular Birliği Dergisi, 4 (16): 22-23.

Çakır, İ. ve Arslan, R. (2018). Türkiye'deki Üniversitelerde Kadın Akademisyenlerin Karşılaştıkları Sorunlar ve Bartın Üniversitesi'nde Çalışan Kadın Akademisyenler Üzerine Bir Araştırma, Bartın Üniversitesi İktisadi ve İdari Bilimler Fakültesi Dergisi, 9 (18): 265- 280.

Dökmen, Z. Y. (2004). Toplumsal Cinsiyet: Toplumsal Psikolojik Açıklamalar. İstanbul: Sistem Yayıncılık.

Elmas Arslan, G. (2014). Türkiye'de Çalışan Kadın Olmak ve Kadın Akademisyenler, Gazi Üniversiteli Öğretim Üyeleri Derneği Bülteni, 12 (1): 36-40.

Er, D. (2008). Modern Türkiye'de Kadın Öğretim Üyelerinin Konumuna ve Sorunlarına Sosyolojik Bir Yaklaşım. (Basılmamış Doktora Tezi). Elazı̆̆: Fırat Üniversitesi Sosyal Bilimler Enstitüsü.

Ergün, M. (1978). II. Meşrutiyet Dönemi'nde Eğitim Hareketleri. (Basılmamış Doktora Tezi). Ankara: Ankara Üniversitesi Dil ve Tarih Coğrafya Fakültesi.

Ersoy, E. (2009). Cinsiyet Kültürü İçerisinde Kadın ve Erkek Kimliği (Malatya Örneği), Firat Üniversitesi Sosyal Bilimler Dergisi, 19 (2): 209-230.

Evren, S. (2018). Mersin Turizm İşletmeciliği ve Otelcilik Yüksekokulu. İçinde N. Kozak (Editör), Dünden Bugüne Türkiye'de Turizm: Kurumlar, Kuruluşlar, Turizm Bölgeleri ve Meslekler (ss.685-714). İstanbul: Y1k1lmazlar Matbaas1.

Gülenç, S. (2018). Balıkesir Turizm İşletmeciliği ve Otelcilik Yüksekokulu. İçinde N. Kozak (Editör), Dünden Bugüne Türkiye'de Turizm: Kurumlar, Kuruluşlar, Turizm Bölgeleri ve Meslekler (ss. 659-684). İstanbul: Y1k1lmazlar Matbaas1.

Kodaman, B. (1980). Abdülhamit Devri Ĕ̆itim Sistemi. İstanbul: Ötüken Yayınevi.

Korzay, M. (1987). Tourism Education in Turkey, International Journal of Hospitality Management, 6(1): 43-48.

Korzay, M. (1994). Turkish Tourism Development. İçinde A.V. Seaton (Editör), Tourism: The State of the Art (ss.8599). New York: John Wiley.

Kozak, M. ve Kozak, N. (2018). Türk Turizmine Kanat Gerenler Cilt 1 Öncü Turizm Eğitimci ve Araştırmacıları. Ankara: Detay Yayıncilık.

Kozak, N., M. Akoğlan Kozak ve M. Kozak. (2017). Genel Turizm: İlkeler ve Kavramlar. Ankara: Detay Yayıncılık.

Kozak, N. (2000). Türkiye de Turizm Literatürünün Gelişim Süreci Üzerine Bir İnceleme, Doğu Akdeniz Üniversitesi Turizm Araştırmaları Dergisi, 1 (1): 16-59.

Kozan Akbayırlı, G. Y. (2016). Kadın Turizm Akademisyenlerinin İşyeri Arkadaşlıklarının Örgüt İklimi Ekseninde Analizi. (Basılmamış Yüksek Lisans Tezi). İzmir: Dokuz Eylül Üniversitesi Sosyal Bilimler Enstitüsü. 
Köker, E. (1988). Türkiye'de Kadın, Eğitim ve Siyaset: Yükseköğrenim Kurumlarında Kadının Durumu Üzerine Bir İnceleme. (Basılmamış Doktora Tezi). Ankara: Ankara Üniversitesi, Siyasal Bilgiler Enstitüsü.

Kurnaz, Ş. (1996). II. Meşrutiyet Dönemi'nde Türk Kadını. İstanbul: Milli Eğitim Basımevi.

Kültür ve Turizm Bakanlığ (2019), http://yigm.kulturturizm. gov.tr/TR-9860/turizm-belgeli-tesisler.html, Erișim tarihi: 4 Mart 2019.

Mayatürk Akyol, E. (2015). Toplumsal Yaşamda ve Çalışma Hayatında Kadın ve Anne Kimlikleri: Kuramsal Bir Bakış. İçinde O. Sürgevil Dalkılıç (Editör), ÇalışAnne: Kadın Akademisyenlerin Kaleminden Çalışma Yaşamında Annelik (ss. 1-30). Ankara: Nobel Yayıncllı.

Naymansoy, G. (2009). Türkiye'de Bilim Kadınları ve Bilimin Gelişimine Katkıları. (Basılmamış Doktora Tezi). Ankara: Ankara Üniversitesi Sosyal Bilimler Enstitüsü.

Okumus, F. ve Yagci, O. (2005).Tourism Higher Education in Turkey, Journal of Teaching in Travel \& Tourism, 5 (1-2): 89-116.

Öktem, Ş., Kubat, G. ve Kızıltan, B. (2018). Otel İşletmelerinde Kadın İşgören Davranışlarını Etkileyen Algılara İliş̧in Bir Araştırma, Anatolia: Turizm Araştırmaları Dergisi, 29 (2): 197-208.

Öncü, A. (1979). Uzman Mesleklerde Türk Kadını (Nermin Abadan UNAT) Türk Toplumunda Kadın. Ankara: Sosyal Bilimler Dermeği Yayını.

Öner, S. ve Özdemirkıran, M. (2017). Uluslararası İlişkiler (Ui) Disiplininin Eril Dili ve Türkiye'de Kadın Uİ Akademisyenlerinin Disiplinin Eril Diline Bakışları, Alternatif Politika, 9 (3): 361-384.

Özkanlı, Ö. ve Korkmaz, A. (2000). Kadın Akademisyenler. AÜ Siyasal Bilgiler Fakültesi Yayını.

Sahilli Birdir, S. (2018). Şule Çetin Portresi: Bir Turizm Öncüsü. İçinde M. Kozak ve N. Kozak (Editörler), Türk Turizme Kanat Gerenler Cilt: I Öncü Turizm Eğitimci ve Araştırmacıları (ss. 439-448). Ankara: Detay Yayıncllık.

Seyidoğlu, H. (1995). Bilimsel Araştırma ve Yazma El Kitabı. 6. Baskı, İstanbul: Gözem Yayınları.

Spuler, B. (1975). Tanzimat ve Atatürk Dönemi'nde Türk Eğitim Sistemleri ve Mukayeseleri, Atatürk Devrimleri I. Milletlerarası Semроzуити Bildirileri, İstanbul: Sermet Matbaas1, 428-439.
Solmaz, S. A. ve Ulema, S. (2014). Türkiye'de Turizm EğitimÖğretiminde Mevcut Durum Üzerine Analitik Bir Değerlendirme, 1. Uluslararası Turizm ve Yönetim Araştırmalar Kongresi Bildiriler Kitabı, 97-115.

Şenesen, G.G. (1996). Türkiye Üniversitelerinin Üst Yönetiminde Kadınların Konumu: 1990-93. İçinde H. Coşkun (Editör), Akademik Yaşamda Kadın (ss. 209-244). Ankara: Türk-Alman Kültür İşleri Kurulu Yayını.

Sevik, S. (2016). MYO'ların Teknik Bilimler Alanlarında Kadın Akademisyen İstihdamının Problematik Bir Yaklaşım ile Değerlendirilmesi, Uluslararası Yükseköğretimde Mesleki Ĕ̆itim ve Öğretim Sempozyumu (ss. 173-184). Çorum: Hitit Üniversitesi.

Tahtalığlu, H. (2016). Türkiye'de Yükseköğretim Kurumlarında Cam Tavan Sendromunun Kadınlar Üzerindeki Etkileri, Niğde Üniversitesi İktisadi ve İdari Bilimler Fakültesi Dergisi, 9(2): 89-105.

Tepe, F. F. (2018). 2000'lerde Türkiye'de Kadın Akademisyenler: Rol Çatışması mı veya Rol Genişlemesi mi?, Yükseköğretim ve Bilim Dergisi, 8(2): 271-279.

Toker, A. (2018). Türkiye'de Bir İlk: Ankara Otelcilik Okulu (1961-1974). İçinde N. Kozak (Editör), Dünden Bugüne Türkiye'de Turizm: Kurumlar, Kuruluşlar, Turizm Bölgeleri ve Meslekler (ss. 565-602). İstanbul: Y1kılmazlar Matbaas1.

Türkiye Seyahay Acentaları Birliği, www.tursab.org.tr/istatistikler/turistik-tesis-isletmeler, Erişim tarihi: 4 Mart 2019.

Ucal, M., O'Neil, M. L.ve Toktas, S. (2015). Gender and the Wage Gap in Turkish Academia, Journal of Balkan and Near Eastern Studies, 17 (4): 447-464.

Ünlüönen, K. ve Boylu, Y. (2005). Türkiye'de Yükseköğretim Düzeyinde Turizm Eğitimindeki Gelişmelerin Değerlendirilmesi, Elektronik Sosyal Bilimler Dergisi, 3 (12): 11-32.

Ünlüönen, K. (1993). Türkiye'de Yüksek Öğretim Düzeyinde Turizm Eğitim ve Öğretimi, Dicle Üniversitesi Hukuk Fakültesi Dergisi, 6: 497-521.

Yeşiltaş, M., Öztürk, Y. ve Hemmington, N. (2010). Tourism Education in Turkey and Implications for Human Resources, Anatolia: An International Journal of Tourism and Hospitality Research, 21 (1): 55-71.

Yıldırım, A. ve Şimşek, H. (2006). Sosyal Bilimlerde Nitel Araştırma Yöntemleri. Ankara: Seçkin Yayınevi.

YÖK İstatistikleri.

2547 Sayılı Yükseköğretim Kanunu.

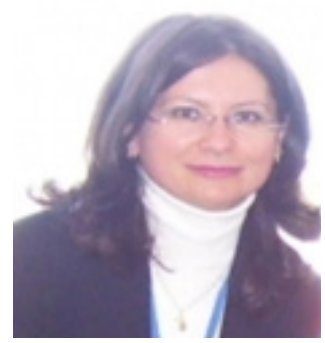

\section{Hatice GÜÇLÜ NERGiz}

Adnan Menderes Üniversitesi Turizm İ̧̧letmeciliği ve Otelcilik Yüksekokulu'ndan mezun oldu (1992). Yüksek lisans derecesini Adnan Menderes Üniversitesi Sosyal Bilimler Enstitüsü Turizm İşletmeciliği Ana Bilim Dalı'ndan (2000), doktora derecesini de Anadolu Üniversitesi Sosyal Bilimler Enstitüsü Turizm ve Otel İşletmeciliği Ana Bilim Dalı'ndan aldı (2006). Doçentlik unvanını Turizm alanında aldı (2017). Adnan Menderes Üniversitesi Turizm Işletmeciliği ve Otelcilik Yüksekokulu'nda Araştırma Görevlisi olarak başladığı (1996) akademik yaşamına Kocaeli Üniversitesi Turizm İşletmeciliği ve Otelcilik Yüksekokulu'nda devam etmektedir. Temel çalışma alanları turizm etiği, otel işletmeciliği, örgütsel davranış ve gastronomidir. 